\title{
Antioxidant potential of essential oil from Lavandula angustifolia in in vitro and ex vivo cultured liver cells
}

\author{
K. KOZICS ${ }^{1, *}$, A. SRANCIKOVA ${ }^{1}$, E. SEDLACKOVA ${ }^{1}$, E. HORVATHOVA ${ }^{1}$, M. MELUSOVA ${ }^{2}$, V. MELUS ${ }^{3}$, Z. KRAJCOVICOVA ${ }^{3}$, M. SRAMKOVA ${ }^{1}$
}

${ }^{1}$ Cancer Research Institute, Biomedical Research Center, Slovak Academy of Sciences, Dubravska 9, 84505 Bratislava, Slovak Republic; ${ }^{2}$ Faculty of Pharmacy, Comenius University, Odbojarov 10, 83232 Bratislava, Slovak Republic; ${ }^{3}$ Department of Laboratory Medicine, Faculty of Healthcare, Alexander Dubcek University of Trencin, Studentská 1639/2, 91150 Trencin, Slovak Republic

*Correspondence: katarina.kozics@savba.sk

Received June 17, 2016/ Accepted December 12, 2016

\begin{abstract}
Lavender is a commonly used herb in traditional medicine in Asia and Europe. It has been reported to be an effective medical plant in treating inflammation, depression and stress, thanks to its sedative and anxiolytic action, thrombotic, and antimicrobial properties. In the present study we investigated the protective effects of essential oil from Lavandula angustifolia (LO) against hydrogen peroxide and tert-butyl hydroperoxide -induced DNA damage. Also the effects of LO on the levels of enzymatic and non-enzymatic antioxidants (SOD-superoxide dismutase, GPx-glutathione peroxidase, GSH-glutathione) were evaluated in in vitro (human hepatoma cell line HepG2) and in ex vivo (freshly isolated rat hepatocytes) systems. The results showed that the oxidant-induced DNA lesions were significantly reduced in both systems pre-treated with the Lavandula angustifolia. The observed DNA-protective activity could be explained by both elevation of GPx activity in cells pre-treated with LO and antioxidant activity of LO.
\end{abstract}

Key words: Lavandula angustifolia, HepG2, primary hepatocytes, oxidative stress, antioxidant enzymes

Oxidative stress reflects an imbalance between the systemic manifestation of reactive oxygen species (ROS) and an ability of biological system to readily detoxify the reactive intermediates or to repair the resulting damage. ROS include free radicals such as superoxide $\left(\mathrm{O}_{2}^{-}\right)$, hydroxyl radical $(\cdot \mathrm{OH})$, peroxyl radical $\left(\mathrm{RO}_{2}\right)$ as well as non-radical species such as hydrogen peroxide $\left(\mathrm{H}_{2} \mathrm{O}_{2}\right)$. Disturbances in the normal redox state of cells can lead to the production of peroxides and free radicals that damage all components of the cell, including proteins, lipids, and DNA. In humans, oxidative stress is thought to be involved in the etiology of many diseases including cancer [1], Parkinson's disease, Alzheimer's disease [2], atherosclerosis, heart failure [3], myocardial infarction [4], fragile X syndrome [5], sickle cell disease [6], lichen planus [7], vitiligo [8], autism [9] and chronic fatigue syndrome [10]. However, reactive oxygen species can be also beneficial, e.g. they are used by the immune system as a way to attack and kill pathogens [11-13].

The effects of ROS/free radicals can be balanced by endogenous antioxidant enzymes including superoxide dismutase (SOD), catalase (CAT), glutathione dependent enzymes such as glutathione peroxidase $(\mathrm{GPx})$, glutathione reductase (GR) as well as by antioxidant compounds such as ascorbic acid, a-tocoferol, glutathione and other dietary antioxidants, which scavenge radicals or neutralize ROS, thus maintaining redox balance [14]. Reduced activities of antioxidant enzymes have been identified e.g. in the serum of patients with non-melanoma skin cancers [15]. Therefore, the antioxidant enzymes and antioxidant molecules are believed to play an important role in prevention of oxidative stress-related diseases such as cancer, cardiovascular disease, Alzheimer's disease and muscular degeneration [16].

Plant- derived essential oils and lipid- soluble bioactive compounds have gained attention for biological roles due to their higher bioavailability compared to water-soluble bioactive compounds. Recently, some essential oils extracted from plants have been reported to have antioxidant effects through scavenging radicals and inducing antioxidant enzymes [17-19]. Lavandula angustifolia (true lavender or English lavender) is a well-known aromatic plant rich in volatile oil which is frequently reported to contain linalool (20-50\% of the fraction) and linalyl acetate (25-46\% of the fraction) as the major oil constituents [20]. The plant was also reported 
to contain phenolics including flavonoids, caffeic acid and derivative of rosmarinic acid [21]. However, there is still a lack of detailed data on the polyphenolic contents as well as on the pharmacological activities of $L$. angustifolia. Majority of results concerning the effects of lavender in different model systems was obtained with lavender oil or with some of the major components of L. angustifolia. Lavender essential oil, volatile aromatic oily liquid isolated from Lavandula plants, possesses many therapeutic properties including antioxidant, anti-inflammatory [22], antimicrobial [23], antiplatelet and antithrombotic [24], antimutagenic [25] and chemopreventive [26] activities. Lavender essential oil is commonly used in aromatherapy and massage. Its major clinical benefits are on the central nervous system. Wang et al. [27] found that treatment with lavender oil significantly decreased neurological deficit scores, infarct size, the levels of malondialdehyde, carbonyl and reactive oxygen species (ROS), upregulated antioxidant enzymes such as superoxide dismutase (SOD), glutathione peroxidase (GPx) and catalase (CAT) activities. These results suggested that the neuroprotective effects of lavender oil against cerebral ischemia/reperfusion injury in mice may be attributed to its antioxidant effects.

In this study we evaluated the potential protective effect of LO against hydrogen peroxide $\left(\mathrm{H}_{2} \mathrm{O}_{2}\right)$ - and tert-butyl hydroperoxide (tBHP)-induced oxidative DNA damage in human hepatoma cell line HepG2 and in freshly isolated rat hepatocytes isolated from animals supplemented with LO. Furthermore, we investigated the effect of $\mathrm{LO}$ treatment on the activity of enzymatic and non-enzymatic antioxidants (namely superoxide dismutase - SOD, glutathione peroxidase - GPx and intracellular glutathione - iGSH) in both (in vitro and ex vivo) systems.

\section{Material and methods}

Chemicals. Lavandula angustifolia (LO) extract (Lavender Flower $\mathrm{CO}_{2}$-se extract, type no. 084.001) was provided by Flavex Naturextrakte GmbH (Rehlingen, Germany). The essential oil was distilled from the flowers of Lavandula angustifolia. The chemical composition determined by GC-MS method given by manufacturer was as follows: $30.1 \%$ linalyl acetate; $25.4 \%$ linalool; 6.5\% 1.8-cineole; $2 \%$ lavandulyl acetate; $0.8 \%$ caryophyllene; $0.75 \%$ a-terpineol; $0.4 \%$ lavandulol; $0.18 \%$ o-cimen; $0.16 \%$ limonen; $0.1 \%$ myrcen and $0.05 \%$ p-cymen. LO extract was kept dry and in the dark place and diluted in DMSO (final concentration was $1 \%$ ). For the experiments, further dilutions were prepared (i) in medium for HepG2 cells, to reach the final concentrations $(0.045-0.9 \mathrm{mg} / \mathrm{ml})$, (ii) in drinking water of rats to reach the final concentrations $(0.1-0.5 \mathrm{mg} / \mathrm{ml} \mathrm{LO})$.

Hydrogen peroxide $\left(\mathrm{H}_{2} \mathrm{O}_{2}\right.$; Sigma, Sigma-Aldrich Co., Steinheim, Germany) was stored at $4^{\circ} \mathrm{C}$ and diluted in phosphate-buffered saline (PBS, $\mathrm{Ca}^{2+}$ and $\mathrm{Mg}^{2+}$ free) to final concentration of $300 \mu \mathrm{M}$ immediately before the treatment of HepG2 cells / hepatocytes. Tetra butyl hydrogen peroxide (tBHP; Sigma, Sigma-Aldrich Co., Steinheim, Germany) was diluted in phosphate-buffered saline ( $\mathrm{PBS}, \mathrm{Ca}^{2+}$ and $\mathrm{Mg}^{2+}$ free) to final concentration of $115 \mu \mathrm{M}$ immediately before the treatment of HepG2 cells and $200 \mu \mathrm{M}$ for primary rat hepatocytes. RANSOD kit was purchased from Randox Laboratories Ltd. (Crumlin, UK) and glutathione reductase, glutathione, NADPH from Sigma-Aldrich Co.

Media, antibiotics and chemicals used for in vitro, and ex vivo experiments were purchased from Gibco BRL (Paisley, UK). All other chemicals were of analytical grade from commercial suppliers.

Cell culture. Malignant cell line HepG2 (human hepatocellular carcinoma cells) was obtained from Prof. A.R. Collins (University of Oslo, Oslo, Norway). The cells were cultured in RPMI 1640 medium supplemented with $10 \%$ fetal calf serum and antibiotics (penicillin $200 \mathrm{U} / \mathrm{ml}$, streptomycin $100 \mu \mathrm{g} / \mathrm{ml}$, kanamycin $100 \mu \mathrm{g} / \mathrm{ml})$ on plastic Petri dishes $(\varnothing=10 \mathrm{~cm})$ at $37^{\circ} \mathrm{C}$ in humidified atmosphere of $5 \% \mathrm{CO}_{2}$

Cytotoxicity of LO in HepG2 cell line. HepG2 cells were seeded into the series of 96 well plates in a density of $2 \times 10^{4} /$ well and cultured in complete RPMI 1640 medium. Exponentially growing cells were then pre-incubated in the presence of LO $(0.045-0.9 \mathrm{mg} / \mathrm{ml}$ ) or without extract (control) for $24 \mathrm{~h}$ and used for testing of cytotoxicity by the MTT assay. MTT test is a colorimetric method for measuring the activity of mitochondrial enzymes that reduce MTT (3-(4,5-dimethylthiazol-2-yl)-2.5-diphentltetrazolium bromide), a yellow tetrazole, to purple formazan. This reduction takes place only when reductase enzymes are active, and therefore conversion is often used as a measure of viable (living) cells. In our experiments, we incubated the properly treated HepG2 cells in $100 \mu \mathrm{l}$ of complete RPMI medium $+50 \mu \mathrm{l}$ of $1 \mathrm{mg} / \mathrm{ml}$ MTT solution for $4 \mathrm{~h}$. For each sample at least 8 wells were used. Then, MTT solution was removed, $100 \mu \mathrm{l}$ of dimethyl sulfoxide (DMSO; Sigma-Aldrich Co., USA) was added to each well and plates were placed on an orbital shaker for $30 \mathrm{~min}$ to completely dissolve the formazan crystals. Absorbance at a wavelength of $540 \mathrm{~nm}$ was measured using an xMark ${ }^{\mathrm{mm}}$ Microplate Spectrophotometer (Bio-Rad Laboratories, Inc.) and background absorbance at $690 \mathrm{~nm}$ was subtracted.

Animals and LO extract supplementation. Adult (8-10 weeks old) male and female Sprague-Dawley (SD) rats weighing 340-410 g, resp. 195-275 g were used. The animals were obtained from AnLab Ltd. (Czech Republic) and maintained one per cage in a temperature- and humidity-controlled room with a $12 \mathrm{~h}$ light-dark cycle. They were given standard diet (M3, Bonagro Inc., Blažovice, Czech Republic) ad libitum. Thirty $\mathrm{ml}$ of lavender extract enriched water per animal was prepared as a daily dose. Four groups $(0,0.1,0.23$ and $0.5 \mathrm{mg}$ of lavender extract $/ \mathrm{ml}$ of water) containing at least three rats (of each gender) were used for experiments.

Lavender extract enriched-water consumption for each rat was recorded daily and individual body weights were measured at the beginning and at the end of experiment. After 14 days of supplementation, the average total body weight gain was 36-88 g. The animal facility of the Cancer Research Institute 
of the Slovak Academy of Sciences (CRI SAS) is authorized to perform scientific research on animals. The Ethics Committee of CRI SAS approved the animal experiments which were performed in full compliance with the European Community Guidelines concerning principles for the care and use of the laboratory animals. At the end of the experiments, the rats were ethically sacrificed by an i.p. dose of thiopental and used for the collection of blood samples and isolation of primary hepatocytes.

Hepatocytes isolation and culture. Hepatocytes were isolated by the two-step in situ collagenase (Sigma, Sigma-Aldrich Co.) liver perfusion technique as described by Michalopoulos et al. [28]. The cell viability assessed just after perfusions by trypan blue (Invitrogen Gibco BRL, Paisley, UK) exclusion was above $60 \%$. According to Eckl et al. [29], the isolated hepatocytes were plated at a density of $5 \times 10^{5}$ viable cells per dish on collagen-coated $60 \mathrm{~mm}$ diameter plastic Petri dishes in $5 \mathrm{ml}$ of MEM containing $1.8 \mathrm{mM} \mathrm{Ca}^{2+}$ and supplemented with non-essential amino acids, pyruvate $(1 \mathrm{mM})$, aspartate $(0.2 \mathrm{mM})$, serine $(0.2 \mathrm{mM})$, penicillin $(100 \mathrm{U} / \mathrm{ml}) /$ streptomycin $(100 \mu \mathrm{g} / \mathrm{ml})$. The cultures were incubated at standard conditions $\left(37^{\circ} \mathrm{C}, 5 \% \mathrm{CO}_{2}\right)$. After an initial incubation period of $2 \mathrm{~h}$, the medium was exchanged for fresh MEM and the cultures were returned to the incubator.

Treatment of primary rat hepatocytes. The hepatocytes isolated from control as well as extracts-supplemented rats were exposed to either $\mathrm{H}_{2} \mathrm{O}_{2}$ or tBHP. Treatment of hepatocytes with $\mathrm{H}_{2} \mathrm{O}_{2}(300 \mu \mathrm{M})$ was carried out with cells embedded in agarose on slides at $4^{\circ} \mathrm{C}$ for $5 \mathrm{~min}$ in the dark. For the treatment $(2 \mathrm{~h})$ with tBHP (dissolved in MEM to the final concentration of $200 \mu \mathrm{M}$ ), we used hepatocytes plated on Petri dishes. After the treatment, the cells were washed, detached with collagenase and embedded in agarose for the comet assay (Horvathova $e t$ al., 1997).

Single cell gel electrophoresis (SCGE, the comet assay). The procedure of Singh et al. [30] was used with minor modifications suggested by Slameňová et al. [31] and Gábelová et al. [32]. Briefly: $2-2.5 \times 10^{4}$ of hepatocytes were spread on a $1 \%$ normal melting point (NMP) agarose pre-coated microscopic slides and covered with a cover slip. After solidification of the gels, the cover slips were removed and treatment with $\mathrm{H}_{2} \mathrm{O}_{2}$ was carried out. The samples of $\mathrm{tBHP}$ were treated with relevant concentrations in Petri dishes $(\varnothing=40 \mathrm{~mm})$ at $37^{\circ} \mathrm{C}$ in a $\mathrm{CO}_{2}$ incubator. The slides containing hepatocytes were then placed in lysis solution $(2.5 \mathrm{M} \mathrm{NaCl}, 100 \mathrm{mM} \mathrm{Na}$ EDTA, $10 \mathrm{mM}$ Tris$\mathrm{HCl}, \mathrm{pH}=10$ and $1 \%$ Triton $\mathrm{X}-100$, at $4^{\circ} \mathrm{C}$ ) for $1 \mathrm{~h}$ to remove cellular proteins. Slides were transferred to an electrophoresis box and immersed in an alkaline solution $(300 \mathrm{mM} \mathrm{NaOH}$, $\left.1 \mathrm{mM} \mathrm{Na} \mathrm{EDTA}_{2} \mathrm{pH}>13\right)$ ). After $40 \mathrm{~min}$ of unwinding time, a voltage of $25 \mathrm{~V}(0.3 \mathrm{~A})$ was applied for $30 \mathrm{~min}$ at $4^{\circ} \mathrm{C}$.

The following steps of unwinding and electrophoresis were identical both in the conventional and modified procedure, i.e. the slides were neutralized with $3 \times 5$ min washes with Tris- $\mathrm{HCl}(0.4 \mathrm{M}, \mathrm{pH}=7.4)$ and stained with ethidium bromide (EtBr, $5 \mu \mathrm{g} / \mathrm{ml}$; Sigma Chemical Company, St. Louis, MO).
EtBr-stained nucleoids were examined with Zeiss Imager. $\mathrm{Z} 2$ fluorescence microscope using the computerized image analysis (Metafer 3.6, MetaSystems $\mathrm{GmbH}$, Altlussheim, Germany). The percentage of DNA in the tail (\% of tail DNA) was used as a parameter for DNA damage measurement. One hundred comets were scored per each sample in one electrophoresis run.

Antioxidant enzyme activity assays. For determination of superoxide dismutase (SOD, EC1.15.1.1) and glutathione peroxidase (GPx, EC1.11.1.9) activities, we used $3 \times 10^{4} \mathrm{HepG} 2$ cells/hepatocytes isolated from control as well as extractssupplemented rats which were solved $1: 1$ in $0.1 \%$ Triton $\mathrm{X}-100$. For determination of SOD we used $1.5 \times 10^{4}$ cells and the RANSOD kit. The method employs xanthine and xanthine oxidase to generate superoxide radicals which react with 2-(4-iodophenyl)-3-(4-nitrophenol)-5-phenyltetrazolium chloride to form a red formozan dye. The activity is measured by the degree of reaction inhibition. For GPx determination according to the method of Paglia and Valentine [33], we used $3 \times 10^{4}$ hepatocytes and cumene hydroperoxide as a substrate.

GSH assay. Intracellular glutathione (iGSH) was measured by flow cytometry using monochlorobimane (MCB; Sigma, Sigma-Aldrich Co., Steinheim, Germany) staining for iGSH. $1-2 \times 10^{6}$ hepatocytes isolated from control and LOsupplemented rats were stained with $40 \mu \mathrm{M} \mathrm{MCB}$ at room temperature for $20 \mathrm{~min}$ in the dark. After several washings, samples were measured at flow cytometry using a Canto II flow cytometer (Becton Dickinson) fitted with 405 and $488 \mathrm{~nm}$ lasers [34].

Serum biochemical parameters. All tested enzyme (AST, ALT, ALP) activities were determined on the analyzer Olympus AU 640 (Olympus Life and Material Science Europa $\mathrm{GmbH}$, Germany) with reagent sets: OSR6209 for AST, OSR6107 for ALT and OSR6204 for ALP (Olympus Life and Material Science Europa, Ireland). The principles of all determinations were based on the testing of enzymatic activity in accordance to IFCC recommendations.

Aspartate transaminase (AST, EC2.6.1.1) catalyzes transamination from $\mathrm{L}$-aspartate to 2-oxoglutarate forming oxalacetate and L-glutamate. In the second step, the oxalacetate is reduced to L-malate with the aid of malate dehydrogenase. Reduction of NADH concentration is measured at $340 \mathrm{~nm}$. For the ensuring the maximal activity of AST in the first step, pyridoxal phosphate is added to the reaction mix.

Alanine aminotransferase (ALT, EC2.6.1.2) transfers the amino group from alanine to 2-oxoglutarate, producing pyruvate and L-glutamate. Pyruvate is subsequently reduced to L-lactate whereby decreases the absorbance of NADH at $340 \mathrm{~nm}$. Endogenous pyruvate is removed during the incubation.

Alkaline phosphatase (ALP, EC3.1.3.1) converts p-nitropehyl phosphate to p-nitrophenol and 2-amino-2-methyl-1-propanol as the phosphate acceptor in the presence of $\mathrm{Mg}^{2+}$ and $\mathrm{Zn}^{2+}$ at $\mathrm{pH}=10.4$. Rate of absorbance change is tested at $410 / 480 \mathrm{~nm}$.

Statistical analysis. Data were analyzed by SPSS 15.0 software. One-sample Kolmogorov-Smirnov test was used to 


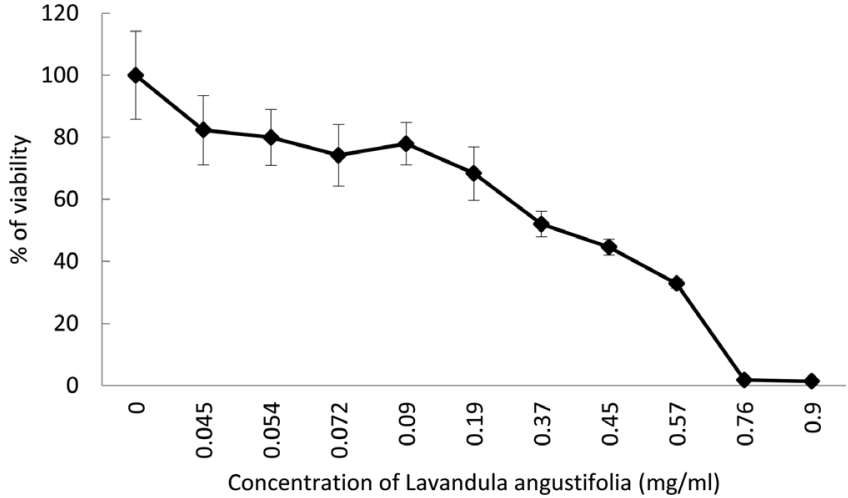

Figure 1. Cytotoxicity/viability of HepG2 cells treated with Lavandula angustifolia extract $(0-0.9 \mathrm{mg} / \mathrm{ml})$ for $24 \mathrm{~h}$. Data represent means $\pm \mathrm{SD}$ of 3 independent experiments.

test normality of datasets distribution. Because all datasets were normally distributed the independent samples $t$-test was performed to test for significant differences between groups. Differences between more than two groups were assessed by one way analysis of variance (ANOVA) followed by the Bonferroni test if equal variances were assumed or Tamhane's test if equal variances were not assumed. The data are expressed as means \pm standard deviations (SD). Differences with $p<0.05$ are considered to be statistically significant.

\section{Results}

Effects of LO extract on HepG2 cell viability. Cytotoxic effect of $24 \mathrm{~h}$ treatment of different concentrations of LO $(0-0.9 \mathrm{mg} / \mathrm{ml})$ extract was evaluated in HepG2 cells by the

Table 1. The activity of enzymes glutathione peroxidase (GPx) and superoxide dismutase (SOD) in HepG2 cells treated with Lavandula angustifolia for $24 \mathrm{~h}$ and hepatocytes isolated from control as well as extracts-supplemented rats.

\begin{tabular}{llcc}
\hline & & $\begin{array}{c}\text { Gpx } \\
\text { (U/mg prot) }\end{array}$ & $\begin{array}{c}\text { SOD } \\
\text { (U/mg prot) }\end{array}$ \\
\hline HepG2 (mg/ml) & Control & $1.269 \pm 0.130$ & $9.944 \pm 0.320$ \\
& 0.09 & $1.458 \pm 0.250$ & $10.75 \pm 1.450$ \\
& 0.19 & $1.555 \pm 0.210^{*}$ & $9.315 \pm 1.260$ \\
& 0.37 & $1.624 \pm 0.130^{* * *}$ & $9.99 \pm 0.560$ \\
\hline Primary rat hepatocytes & Control & $0.457 \pm 0.011$ & $1.658 \pm 0.370$ \\
(mg/ml) & 0.13 & $0.606 \pm 0.021^{*}$ & $2.290 \pm 0.430^{*}$ \\
female & 0.50 & $0.993 \pm 0.013^{* *}$ & $2.20 \pm 0.400$ \\
& Control & $0.461 \pm 0.019$ & $1.663 \pm 0.290$ \\
Primary rat hepatocytes & 0.10 & $0.598 \pm 0.031^{*}$ & $2.311 \pm 0.330^{*}$ \\
(mg/ml) & 0.23 & $1.015 \pm 0.009^{* *}$ & $2.41 \pm 0.380^{*}$ \\
male & 0.50 & $1.222 \pm 0.051^{* *}$ & $2.125 \pm 0.220^{*}$ \\
\hline
\end{tabular}

Data represent means \pm SD of 5 independent experiments. ${ }^{\star} \mathrm{P}<0.05 ;{ }^{*} \mathrm{P}<$ 0.01 and ${ }^{* *} \mathrm{P}<0.001$ indicate significant differences compared to the control.
MTT assay. The results are summarized in Figure $1 . \mathrm{IC}_{50}$ value (median inhibitory concentrations that cause approximately $50 \%$ cell death) represented: $0.37 \mathrm{mg} / \mathrm{ml}$ of LO extract. Further studies aimed at genotoxic and DNA-protective effects of LO extracts were assessed at IC $\sim_{10-40}$.

DNA-protective effect of LO extract against DNA strand breaks induced by $\mathrm{H}_{2} \mathrm{O}_{2}$. The level of DNA single strand breaks induced in HepG2cells and primary rat hepatocytes by $\mathrm{H}_{2} \mathrm{O}_{2}$ was determined by the SCGE. HepG2 cells were prior to $\mathrm{H}_{2} \mathrm{O}_{2}$ treatment incubated for $24 \mathrm{~h}$ in the presence of $\mathrm{LO}$ extract $(0-0.37 \mathrm{mg} / \mathrm{ml})$. Primary rat hepatocytes were isolated from animals supplemented with LO $(0-0.5 \mathrm{mg} / \mathrm{ml}$ in drinking water) for 14 days. The reduction of $\mathrm{H}_{2} \mathrm{O}_{2}$-induced DNA damage by LO is shown in Figure 2. Our results showed that the levels of DNA lesions induced by $\mathrm{H}_{2} \mathrm{O}_{2}$ were significantly decreased by LO at the concentrations of 0.19 and $0.37 \mathrm{mg} / \mathrm{ml}$ in HepG2 cells, and at all concentrations in primary rat hepatocytes, respectively. No significant difference in response to LO pre-treatment was detected between genders. The level of DNA strand breaks induced in both experimental systems by extract LO alone did not differ significantly from the level of DNA strand breaks in untreated control cells (data not shown).

DNA-protective effects of LO extract against DNA strand breaks induced by tBHP. Figure 3 presents the level of DNA damage induced with $\mathrm{tBHP}$ as detected by comet assay in HepG2cells and primary rat hepatocytes. The results were similar to the results found in $\mathrm{H}_{2} \mathrm{O}_{2}$-induced DNA damage. Our results showed that the levels of DNA lesions induced by tBHP were significantly reduced by extract LO in both experimental systems in vitro and ex vivo, respectively.

Effect of LO on antioxidant status. To determine the effect of pre-treatment with LO (in HepG2 cell and in primary hepatocytes isolated from LO supplemented animals) on antioxidant status, iGSH content, superoxide dismutase (SOD) activity and glutathione peroxidase (GPx) activities were measured.

Table 1 shows that the activity of SOD in primary rat hepatocytes was significantly increased compared to the values from hepatocytes isolated from control animals, whereas treatment of HepG2 cells with LO had no effect. On the other hand, activity of GPx in the both experimental systems was increased significantly by dose-dependent manner. This increase was more significant in primary hepatocytes. GSH contents were determined using MCB staining for flow cytometry, however no effect of LO extract on the iGSH content in either HepG2 or primary hepatocytes was detected when compared to the untreated control cells (data not show).

Serum biochemical parameters. We estimated serum activities of three enzymes: aspartate transaminase (AST), alanine aminotransferase (ALT) and alkaline phosphatase (ALP) in blood plasma of control animals as well as of rats supplemented with LO (Table 2). The levels of ALP in female or male primary rat hepatocytes were significantly reduced (in male- $0.5 \mathrm{mg} / \mathrm{ml}$; in female- $0.23,0.5 \mathrm{mg} / \mathrm{ml}$ ) by LO extract. On the other hand, level of ALT was significantly decreased 




Figure 2. The levels of DNA damage in HepG2 cells pre-treated with Lavandula angustifolia extract for $24 \mathrm{~h}$ or in hepatocytes isolated from control as well as extracts-supplemented rats and then exposed to $300 \mu \mathrm{M}$ $\mathrm{H}_{2} \mathrm{O}_{2}$. White or black bars symbolized negative or positive control and grey bars combination effect of $\mathrm{H}_{2} \mathrm{O}_{2} /$ LO. Data represent means $\pm \mathrm{SD}$ of 5 independent experiments. ${ }^{\star} \mathrm{P}<0.05 ;{ }^{\star *} \mathrm{P}<0.01$ and ${ }^{\star *}{ }^{\star} \mathrm{P}<0.001$ indicate significant differences compared to $\mathrm{H}_{2} \mathrm{O}_{2}$.

only in the female primary rat hepatocytes by dose-dependent manner. Ratio ALT/AST as a parameter of liver [35] injury was analyzed for female and male rats, and did not show any significant gender differences (data not shown).

\section{Discussion}

Recently, there is an increasing interest in the use of natural substances, either pure compounds or complex plant extracts, which possess the ability to scavenge free radicals. Plant extracts are rich in so called secondary metabolites which provide for plant e.g. defense against biological agents or protection against UV radiation [36]. Essential oils (EO), concentrated hydrophobic liquids, containing volatile aromatic compounds such as terpenes and phenols, represent examples of them. Based on the cyclical system of conjugated double bonds in the molecule of the compound, spatial arrangement and the various substituents it can be assumed that many of EO manifest antioxidant properties [37-39]. A great advantage of EO is that they are able to penetrate into a tissue up to 100-times faster than water [40]. They may act within cells either directly as antioxidants (to scavenge

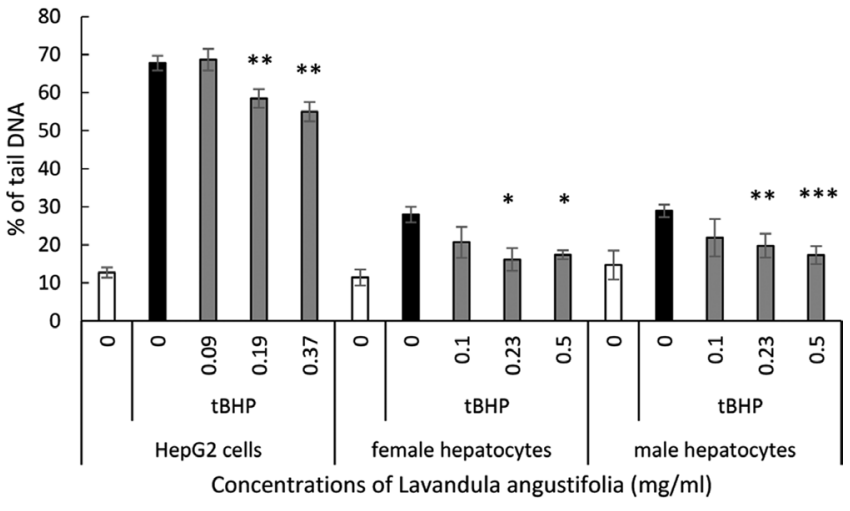

Figure 3. The levels of DNA damage in HepG2 cells pre-treated with Lavandula angustifolia extract for $\mathbf{2 4} \mathrm{h}$ or in hepatocytes isolated from control as well as extracts-supplemented rats and then exposed to $115 \mu \mathrm{M} \mathrm{tBHP}$ for HepG2 cells and $200 \mu \mathrm{M}$ tBHP for primary rat hepatocytes. White or black bars symbolized negative or positive control and grey bars combination effect of $\mathrm{tBHP}$ / LO. Data represent means $\pm S D$ of 5 independent experiments. ${ }^{\star} \mathrm{P}<0.05$; ${ }^{\star \star} \mathrm{P}$ $<0.01$ and ${ }^{\star * *} \mathrm{P}<0.001$ indicate significant differences compared to tBHP.

ROS and other radicals in the cytoplasm) or indirectly, by activating endogenous antioxidant enzymes (SOD, CAT and GPx) or the transcription factors that control the redox balance of the cell $[41,42]$. EO of lavender (Lavandula angustifolia) has long been used in folk medicine, cosmetics and aromatherapy $[43,44]$. Several studies confirmed that LO is useful in the treatment of skin ulcers [45], lesions [46] and burns, thanks to its analgesic and anti-microbial properties [23]. Antibacterial effects of LO were proved against MRSA (methicillin-resistant Staphylococcus aureus) [47], Propionibacterium acnes [48] and Candida albicans [49]. LO also partially helps against fungal diseases of the feet (Trycophyton rubrum and T. mentagrophytes) and calms the skin with herpes zoster [50]. There is relatively little information dealing with the antioxidant properties of LO. Biochemical analysis (2.2-diphenyl-1-picrylhydrazyl-DPPH and 2.2'-azino-bis(3-ethylbenzothiazoline-6-sulphonic acid)- ABTS assays) and our preliminary results suggest that LO may display antioxidant activity [51]. Cadet and Douki [52] found out that in in vitro experiments LO inhibited the production of singlet oxygen $\left({ }^{1} \mathrm{O}_{2}\right)$, the main photoproduct of UVA. On the other hand, UV light caused degradation of

Table 2. The effect of Lavandula angustifolia consumption on activity of liver biochemical parameters in hepatocytes of female and male rats isolated from control as well as extracts-supplemented rats.

\begin{tabular}{lccccc}
\hline & \multicolumn{2}{c}{ AST $(\mu \mathrm{kat} / \mathrm{l})$} & \multicolumn{2}{c}{ ALT $(\mu \mathrm{kat} / \mathrm{l})$} \\
LO oil supplementation & Females & Males & Females & Males $(\mu \mathrm{kat} / \mathrm{l})$ & \multicolumn{2}{c}{ Females } \\
\hline Control & $1.60 \pm 0.214$ & $1.62 \pm 0.297$ & $0.93 \pm 0.101$ & $0.90 \pm 0.062$ & $4.70 \pm 0.396$ \\
$0.10 \mathrm{mg} / \mathrm{ml}$ & $1.75 \pm 0.320$ & $1.62 \pm 0.316$ & $0.76 \pm 0.093$ & $0.71 \pm 0.114$ & $3.42 \pm 0.625$ \\
$0.23 \mathrm{mg} / \mathrm{ml}$ & $1.51 \pm 0.285$ & $1.58 \pm 0.021$ & $0.72 \pm 0.045^{*}$ & $0.80 \pm 0.045$ & $3.38 \pm 0.551^{*}$ \\
$0.50 \mathrm{mg} / \mathrm{ml}$ & $1.32 \pm 0.134$ & $1.90 \pm 0.125$ & $0.69 \pm 0.039^{* *}$ & $0.95 \pm 0.157$ & $3.10 \pm 0.479^{*}$ \\
\hline
\end{tabular}

Data represent means \pm SD of 5 independent experiments. ${ }^{\star} \mathrm{P}<0.05 ;{ }^{* *} \mathrm{P}<0.01$ and ${ }^{* * *} \mathrm{P}<0.001$ indicate significant differences compared to the control. 
secondary metabolites in the $\mathrm{LO}$ resulting in a reduction of its antioxidant activity [53].

A variety of crude plant extracts has been also reported to show hepatoprotective activity and may be useful in the treatment of various liver diseases with different etiology $[54,55]$. In the present study, we have demonstrated DNAprotective effects of lavender oil against two oxidative agents $\left(\mathrm{H}_{2} \mathrm{O}_{2}\right.$ and $\left.\mathrm{tBHP}\right)$ in in vitro and ex vivo conditions, i.e. in human hepatoma cell line HepG2 and in primary rat hepatocytes isolated from animals supplemented by LO. First, the cytotoxicity of LO was determined in HepG2 by MTT assay. Our results showed that $24 \mathrm{~h}$ treatment of cells with LO affected cell viability in a dose dependent manner; $\mathrm{IC}_{50}$ equaled $0.37 \mathrm{mg} / \mathrm{ml}$. Farshori et al. [56] found that all the four extracts of $L$. coronopifolia (namely petroleum ether extract, chloroform extract, ethyl acetate extract, and alcoholic extract) in concentration up to $50 \mathrm{mg} / \mathrm{ml}$ did not cause any significant effect on cell viability of HepG2 cells. Findings indicated that aqueous extract of $L$. angustifolia inhibited cell proliferation in both lymphocytes and cell lines with different effects. The effective concentration of lavender that decreased viability of Hodgkin's lymphoma cells below $\mathrm{LC}_{50}$ (lethal concentration) value was $100 \mu \mathrm{g} / \mathrm{ml}$ and this was half of the therapeutic dose. In addition, apoptosis was the main mechanism the Hodgkin's lymphoma cell encountered when exposed to the aqueous extract of lavender [57].

Induced intracellular ROS generation in HepG2 cells indicated that $\mathrm{H}_{2} \mathrm{O}_{2}$ and $\mathrm{tBHP}$ cause oxidative stress, leading to hepatotoxicity. $\mathrm{H}_{2} \mathrm{O}_{2}$ induces predominantly DNA breaks via the formation of $\cdot \mathrm{OH}$ radicals by the Haber-Weiss reaction, which is catalyzed by ferric ion. Like all reactive oxygen species, it is generated from nearly all sources of the oxidative cycle and has the ability to diffuse in and out of cells and tissues. Among ROS, $\mathrm{OH}$ has an extremely high reactivity with DNA, lipids and proteins, leading to cellular injury [58]. The second oxidant used in our study was tBHP which can be metabolized to free radical intermediates by cytochrome P450 (in hepatocytes) or hemoglobin (in erythrocytes). This can subsequently lead to decomposition to peroxyl radicals, generation of lipid peroxides and ROS [59] thus affecting cell integrity.

It is well known that administration of natural products can suppress increased level of intracellular ROS [60]. Also our previous studies reported that natural extracts administration protects cells against exogenous oxidative damage, improves antioxidant status of cells or affects biochemical serum parameters [61-63]. In the current study pretreatment with lavender oil showed its preventive effects against oxidant-induced DNA damage in HepG2 cells. DNA protective effect of LO was even more prominent in primary hepatocytes isolated from animals supplemented with drinking water with added LO compared to HepG2 cells.

Human body has an effective defense system to protect and neutralize free radical-induce damage. This is accomplished by endogenous antioxidant enzymes such as CAT, SOD, and GPx. These enzymes constitute a mutually supportive team of defense against ROS [64]. We have investigated the activities of following antioxidants enzymes: SOD and GPx and non-enzyme iGSH in cells pretreated with LO. SOD and GPx enzymes catalyze the complete chain reaction in which superoxide anion, the first produced ROS, is sequentially converted into water [65]. The enzymes SOD and GPx act by reducing the rate of production of new radicals; therefore, they are referred to as preventive antioxidants [66]. In the present study LO significantly increased the activity of SOD only in primary rat hepatocytes while the activity of GPx was increased significantly by dose-dependent manner in both experimental systems. Our observations are in a good agreement with our previous results when were used natural extracts namely, sage and thyme $[61,63]$.

When assessing the effectiveness of the defense system against free radical damage in experimental animals it is important to know the functionality of the metabolic state, especially the liver. Therefore, the markers: AST, ALT and ALP were selected and the effect of the supplementation with LO was evaluated as a change in these biochemical parameters in blood serum, since they are commonly used for investigating and recognition induced liver toxicity $[67,68]$. Several types of biochemical parameters have been reported (i) hepatocyte membrane 'leakage' enzymes; (ii) cholestatic-induction parameters and (iii) parameters related to liver function deficits. The hepatic 'leakage' enzymes (including AST and ALT) 'leakout' from the membrane of hepatocytes into peripheral blood. This is followed by hepatocellular injury or alterations in liver membrane permeability. ALP is considered as a cholestatic-induction enzyme of the hepatobiliary origin and shows minimal activity in normal hepatic tissue. Abnormalities in liver cells or in the bile duct can be detected by elevated liver enzymes [69]. It has been demonstrated by us and other groups that other plant extracts (thyme oil, sage and thyme extracts) did not show any significant changes in body weight, food intake, biochemical parameters or histological pattern of the liver [63, $70,71]$ in rats supplemented with these natural compounds of plant origin. Our biochemical analysis showed no significant differences in enzymatic activities of AST in LO supplemented animals and controls. For the ALT levels, we detected slightly decreased levels in female rats, however in male group, no difference was observed. Male rats supplemented with $0.5 \mathrm{mg} / \mathrm{ml}$ of LO, as well as females $(0.23$ and $0.5 \mathrm{mg} / \mathrm{ml})$ had reduced levels of ALP. Interestingly, also our previous study with sage and thyme extract-supplemented rats confirmed lower levels of biochemical parameters [63].

The essential oil from Lavandula angustifolia might be useful as a natural ingredient for the prevention of oxidative damage in liver cells and tissue. In summary, our findings revealed that the $\mathrm{H}_{2} \mathrm{O}_{2}$ /tBHP-induced oxidative stress-mediated cell death in $\mathrm{HepG} 2 /$ primary rat cells could be to some extent prevented by pre-treatment with L. angustifolia through reduction of oxidative stress. L. angustifolia may have protective antioxidant and hepatoprotective properties and offer new alternatives to the limited therapeutic options to treat the liver diseases. 
Acknowledgements: The authors thank Bozena Smolkova, PhD. for her assistance with the statistical analysis of results and Mrs. Anna Moravkova for excellent technical assistance during experiments. This work was supported by the contributions from the Scientific Grant Agency of the Ministry of Education of Slovak Republic and the Academy of Sciences (VEGA) grant 2/0012/12, 2/0027/16 the project implementations: TRANSMED, ITMS: 26240120008 and ITMS: 26240220071 and TRANSMED 2, ITMS: 26240120030 supported by the Research \& Development Operational Programme funded by the ERDF.

\section{References}

[1] HALLIWELL B Oxidative stress and cancer: have we moved forward? Biochem J 2007; 401: 1-11. https://doi.org/10.1042/ $\underline{\text { BJ20061131 }}$

[2] VALKO M, LEIBFRITZ D, MONCOL J, CRONIN MTD, MAZUR $M$ et al. Free radicals and antioxidants in normal physiological functions and human disease. Int J Biochem Cell Biol 2007; 39: 44-84. https://doi.org/10.1016/j.biocel.2006.07.001

[3] SINGH N, DHALLA AK, SENEVIRATNE C, SINGAL PK Oxidative stress and heart failure. Mol Cell Biochem 1995; 147: 77-81. https://doi.org/10.1007/BF00944786

[4] RAMOND A, GODIN-RIBUOT D, RIBUOT C, TOTOSON $\mathrm{P}$, KORITCHNEVA I et al. Oxidative stress mediates cardiac infarction aggravation induced by intermittent hypoxia. Fundam Clin Pharmacol 2013; 27: 252-261.

[5] DE DIEGO-OTERO Y, ROMERO-ZERBO Y, EL BEKAY R, DECARA J, SANCHEZ L I et al. Alpha-tocopherol protects against oxidative stress in the fragile $\mathrm{X}$ knockout mouse: an experimental therapeutic approach for the Fmr1 deficiency. Neuropsychopharmacology 2009; 34: 1011-1026. https://doi. org/10.1038/npp.2008.152

[6] AMER J, GHOTI H, RACHMILEWITZ E, KOREN A, LEVIN C et al. Red blood cells, platelets and polymorphonuclear neutrophils of patients with sickle cell disease exhibit oxidative stress that can be ameliorated by antioxidants. $\mathrm{Br} \mathrm{J}$ Haematol 2006; 132: 108-113. https://doi.org/10.1111/j.13652141.2005.05834.X

[7] ALY DG, SHAHIN RS Oxidative stress in lichen planus. Acta Dermatovenerol Alp Panonica Adriat 2010; 19: 3-11.

[8] ARICAN O, KURUTAS EB Oxidative stress in the blood of patients with active localized vitiligo. cta Dermatovenerol Alp Panonica Adriat 2008; 17: 12-16.

[9] JAMES SJ, CUTLER P, MELNYK S, JERNIGAN S, JANAK L et al. Metabolic biomarkers of increased oxidative stress and impaired methylation capacity in children with autism. Am J Clin Nutr 2004; 80: 1611-1617.

[10] KENNEDY G, SPENCE VA, MCLAREN M, HILL A, UNDERWOOD $\mathrm{C}$ et al. Oxidative stress levels are raised in chronic fatigue syndrome and are associated with clinical symptoms. Free Radic Biol Med 2005; 39: 584-589. https:// doi.org/10.1016/j.freeradbiomed.2005.04.020

[11] HEYMAN SN, ROSEN S, ROSENBERGER C A role for oxidative stress. Contrib Nephrol 2011; 174: 138-148. https://doi. org/10.1159/000329383
[12] WHALEY-CONNELL A, MCCULLOUGH PA, SOWERS JR The role of oxidative stress in the metabolic syndrome. Rev Cardiovasc Med 2011; 12: 21-29. http://dx.doi.org/10.3909/ $\underline{\text { ricm } 0555}$

[13] ARUOMA OI, GROOTVELD M, BAHORUN T Free radicals in biology and medicine: from inflammation to biotechnology. Biofactors 2006; 27: 1-3. https://doi.org/10.1002/ biof.5520270101

[14] DATTA K, SINHA S, CHATTOPADHYAY P REACTIVE OXYGEN SPECIES IN HEALTH AND DISEASE. Natl Med J India 2000; 13: 304-310.

[15] KOBAYASHI T, MATSUMOTO M, IIZUKA H, SUZUKI K, TANIGUCHI N Superoxide dismutase in psoriasis, squamous cell carcinoma and basal cell epithelioma: an immunohistochemical study. Br J Dermatol 1991; 124: 555-559. https://doi. org/10.1111/j.1365-2133.1991.tb04950.x

[16] WINTERBOURN CC Nutritional antioxidants: their role in disease prevention. N Z Med J 1995; 108: 447-449.

[17] NDOYE FOE FM, TCHINANG TF, NYEGUE AM, ABDOU JP, YAYA AJ et al. Chemical composition, in vitro antioxidant and anti-inflammatory properties of essential oils of four dietary and medicinal plants from Cameroon. BMC Complement Altern Med 2016; 16: 117. https://doi.org/10.1186/ s12906-016-1096-y

[18] PLACHA I, RYZNER M, COBANOVA K, FAIXOVA Z, FAIX S Effects of dietary supplementation with sage (Salvia officinalis L.) essential oil on antioxidant status and duodenal wall integrity of laying strain growers. Pol J Vet Sci 2015; 18: 741-749. https://doi.org/10.1515/pjvs-2015-0096

[19] SRIVASTAVA U, OJHA S, TRIPATHI NN, SINGH P In vitro antibacterial, antioxidant activity and total phenolic content of some essential oils. J Environ Biol 2015; 36: 1329-1336.

[20] EUROPEAN MEDICINES AGENCY Assessment report on Lavandula angustifolia Mill., aetheroleum and Lavandula angustifolia Mill., flos. EMA/HMPC 2011; 143183/2010.

[21] MILIAUSKAS G, VENSKUTONIS PR, BEEK TA Screening of radical scavenging activity of some medicinal and aromatic plant extracts. Food Chem 2004; 85: 231-237. https://doi. org/10.1016/j.foodchem.2003.05.007

[22] DA SILVA GL, LUFT C, LUNARDELLI A, AMARAL RH, MELO DA et al. Antioxidant, analgesic and anti-inflammatory effects of lavender essential oil. An Acad Bras Cienc 2015; 87: 1397-1408. https://doi.org/10.1590/0001-3765201520150056

[23] PRUSINOWSKA R, SMIGIELSKI K, STOBIECKA A, KUNICKA-STYCZYNSKA A Hydrolates from lavender (Lavandula angustifolia) - their chemical composition as well as aromatic, antimicrobialand antioxidant properties. Nat Prod Res 2016; 30: 386-393. https://doi.org/10.1080/1 $\underline{4786419.2015 .1016939}$

[24] BALlBENI V, TOGNOLINI M, CHIAVARINI M, IMPICCIATORE M, BRUNI R et al. Novel antiplatelet and antithrombotic activities of essential oil from Lavandula hybrida reverchon „grosso“. Phytomedicine 2004; 11: 596-601. https://doi.org/10.1016/j.phymed.2004.01.002

[25] EVANDRI MG, BATTINELLI L, DANIELE C, MASTRANGELO S, BOLLE $P$ et al. The antimutagenic activity of Lavandula angustifolia (lavender) essential oil in the bacte- 
rial reverse mutation assay. Food Chem Toxicol 2005; 43: 1381-1387. https://doi.org/10.1016/j.fct.2005.03.013

[26] LAI PK, ROY J Antimicrobial and chemopreventive properties of herbs and spices. Curr Med Chem 2004; 11: 1451-1460. https://doi.org/10.2174/0929867043365107

[27] WANG D, YUAN X, LIU T, LIU L, HU Y et al. Neuroprotective activity of lavender oil on transient focal cerebral ischemia in mice. Molecules 2012; 17: 9803-9817. https:// doi.org/10.3390/molecules 17089803

[28] MiCHALOPOUlOS G, CiANCIULli HD, NOVOTNY AR, KLIGERMAN AD, STROM SC et al. Liver regeneration studies with rat hepatocytes in primary culture. Cancer Res 1982; 42: 4673-4682.

[29] ECKL PM, WHITCOMB WR, MICHALOPOULOS G, JIRTLE RL Effects of EGF and calcium on adult parenchymal hepatocyte proliferation. J Cell Physiol 1987; 132: 363-366. https://doi.org/10.1002/jcp.1041320225

[30] SINGH NP, MCCOY MT, TICE RR, SCHNEIDER EL A simple technique for quantification of low levels of DNA damage in individual cells. Exp Cell Res 1988; 175: 184-191. https://doi.org/10.1016/0014-4827(88)90265-0

[31] SLAMENOVA D, GABELOVA A, RUZEKOVA L, CHALUPA I, HORVATHOVA E et al. Detection of MNNG-induced DNA lesions in mammalian cells; validation of comet assay against DNA unwinding technique, alkaline elution of DNA and chromosomal aberrations. Mutat Res 1997; 383: 243-252. https://doi.org/10.1016/S0921-8777(97)00007-4

[32] GABELOVA A, SLAMENOVA D, RUZEKOVA L, FARKASOVA T, HORVATHOVA E Measurement of DNA strand breakage and DNA repair induced with hydrogen peroxide using single cell gel electrophoresis, alkaline DNA unwinding and alkaline elution of DNA. Neoplasma, 1997; 44: 380-383.

[33] PAGLIA DE, VALENTINE WN Studies on the quantitative and qualitative characterization of erythrocyte glutathione peroxidase. J Lab Clin Med 1967; 70: 158-169.

[34] KAMENCIC H, LYON A, PATERSON PG, JUURLINK BH Monochlorobimane fluorometric method to measure tissue glutathione. Anal. Biochem. 2000; 286: 35-37. https://doi. org/10.1006/abio.2000.4765

[35] BOTROS M, SIKARIS KA The de ritis ratio: the test of time. Clin Biochem Rev. 20130; 34: 117-130.

[36] SILVA AR, SEIDL C, FURUSHO AS, BOENO MM, DIEAMANT GC et al. In vitro evaluation of the efficacy of commercial green tea extracts in UV protection. Int J Cosmet Sci 2013; 35: 69-77. https://doi.org/10.1111/ics.12006

[37] MIRI A, MONSEF-ESFAHANI HR, AMINI M, AMANZADEH Y, HADJIAKHOONDI A et al. Comparative Chemical Composition and Antioxidant Properties of the Essential Oils and Aromatic Water from Teucrium persicum Boiss. Iran J Pharm Res 2012; 11: 573-581.

[38] DADKHAH A, FATEMI F, ALIPOUR M, GHADERI Z, ZOLFAGHARI $F$ et al. Protective effects of Iranian Achillea wilhelmsii essential oil on acetaminophen-induced oxidative stress in rat liver. Pharm Biol 2015; 53: 220-227. https://doi. org/10.3109/13880209.2014.913298

[39] SIEBERT DA, TENFEN A, YAMANAKA CN, DE CORDOVA CMM, SCHARF DR et al. Evaluation of seasonal chemical composition, antibacterial, antioxidant and anticholinesterase activity of essential oil from Eugenia brasiliensis Lam. Nat Prod Res 2015; 29: 289-292. https:// doi.org/10.1080/14786419.2014.958736

[40] NWEZE EI, OKAFOR JI In vitro activity of conventional antifungal agents against Scedosporium apiospermum isolates recovered from clinical and environmental samples in Nigeria. Acta Microbiol Immunol Hung 2010; 57: 209-214. https://doi. org/10.1556/AMicr.57.2010.3.5

[41] JU EM, LEE SE, HWANG HJ, KIM JH Antioxidant and anticancer activity of extract from Betula platyphylla var. japonica. Life Sci 2004; 74: 1013-1026. https://doi.org/10.1016/j. $\underline{\text { lfs.2003.07.025 }}$

[42] DAI J, MUMPER RJ Plant phenolics: extraction, analysis and their antioxidant and anticancer properties. Molecules 2010; 15: 7313-7352. https://doi.org/10.3390/molecules15107313

[43] Soheili M, Tavirani MR, SALAMI M Lavandula angustifolia extract improves deteriorated synaptic plasticity in an animal model of Alzheimer's disease. Iran J Basic Med Sci 2015; 18: $1147-1152$

[44] LESAGE-MEESSEN L, BOU M, SIGOILLOT JC, FAULDS $\mathrm{CB}$, LOMASCOLO A Essential oils and distilled straws of lavender and lavandin: a review of current use and potential application in white biotechnology. Appl Microbiol Biotechnol 2015; 99: 3375-3385. https://doi.org/10.1007/ s00253-015-6511-7

[45] GUBA R Wound healing: a pilot study using an essential oil-based cream to heal dermal wounds and ulcers. Int J Aromather 1998/1999; 9: 67-74. https://doi.org/10.1002/rcs.1430

[46] HARTMAN D, COETZEE JC Two US practitioners' experience of using essential oils for wound care. J Wound Care 2002; 11: 317-320. https://doi.org/10.12968/ jowc.2002.11.8.26432

[47] EDWARDS-JONES V, BUCK R, SHAWCROSS SG, DAWSON MM, DUNN K The effect of essential oils on methicillin-resistant Staphylococcus aureus using a dressing model. Burns 2004; 30: 772-777. https://doi.org/10.1016/j. burns.2004.06.006

[48] ZU Y, YU H, LIANG L, FU Y, EFFERTH T et al. Activities of ten essential oils towards Propionibacterium acnes and PC-3, A-549 and MCF-7 cancer cells. Molecules 2010; 15: 3200-3210. https://doi.org/10.3390/molecules 15053200

[49] BEHMANESH F, PASHA H, SEFIDGAR AA, TAGHIZADEH M, MOGHADAMNIA AA et al.Antifungal Effect of Lavender Essential Oil (Lavandula angustifolia) and Clotrimazole on Candida albicans: An In Vitro Study Scientifica (Cairo) 2015; 261397. https://doi.org/10.1155/2015/261397

[50] CASSELLA S, CASSELLA JP, SMITH I Synergistic antifungal activity of tea tree (Melaleuca alternifolia) and lavender (Lavandula angustifolia) essential oils against dermatophyte infection. I J Aromather 2002; 12: 2-15. https://doi. org/10.1054/ijar.2001.0127

[51] CARRASCO A, MARTINEZ-GUTIERREZ R, TOMAS V, TUDELA J Lavandula angustifolia and Lavandula latifolia Essential Oils from Spain: Aromatic Profile and Bioactivities Planta Med 2016; 82: 163-170. https://doi. org/10.1055/s-0035-1558095 
[52] CADET J, DOUKI T Oxidatively generated damage to DNA by UVA radiation in cells and human skin. J Invest Dermatol 2011, 131: 1005-1007. https://doi.org/10.1038/ jid.2011.51

[53] GISMONDI A, CANUTI L, GRISPO M, CANINI A Biochemical Composition and Antioxidant Properties of Lavandula angustifolia Miller Essential Oil are Shielded by Propolis Against UV Radiations. Photochem Photobio Sci 2014; 90: 702-708. https://doi.org/10.1111/php.12229

[54] AWAAD AS, SOLIMAN GA, EL-SAYED DF, EL-GINDI OD, ALQASOUMI SI Hepatoprotective activity of Cyperus alternifolius on carbon tetrachloride-induced hepatotoxicity in rats. Pharm Biol 2012; 50: 155-161. https://doi.org/10.31 $\underline{09 / 13880209.2011 .580351}$

[55] TATIYA AU, SURANA SJ, SUTAR MP, GAMIT NH Hepatoprotective effect of poly herbal formulation against various hepatotoxic agents in rats. Pharmacognosy Res 2012; 4: 50-56. https://doi.org/10.4103/0974-8490.91040

[56] FARSHORI NN, AL-SHEDDI ES, AL-OQAIL MM, HASSAN WH, AL-KHEDHAIRY AA et al. Hepatoprotective potential of Lavandula coronopifolia extracts against ethanol induced oxidative stress-mediated cytotoxicity in HepG2 cells. Toxicol Ind Health 2015; 31: 727-737. https://doi. org/10.1177/0748233713483188

[57] DALILAN S, REZAEI-TAVIRANI M, NABIUNI M, HEIDARI-KESHEL S, AZODI MZ et al. Aqueous Extract of Lavender Angustifolia Inhibits Lymphocytes Proliferation of Hodgkin's Lymphoma Patients. Iran J Cancer Prev 2013; 6: 201-208.

[58] BARBOUTI A, DOULIAS PT, NOUSIS L, TENOPOULOU M, GALARIS D DNA damage and apoptosis in hydrogen peroxide-exposed Jurkat cells: bouls addition versus continuous generation of H2O2. Free Rad Biol Med 2002; 33: 691-702. https://doi.org/10.1016/S0891-5849(02)00967-X

[59] HÖGBERG J, MOLDEUS P, ARBORGH B, O'BRIEN PJ, ORRENIUS S The consequences of lipid peroxidation in isolated hepatocytes. Eur J Biochem 1975; 59: 457-462. https://doi. org/10.1111/j.1432-1033.1975.tb02474.x

[60] DA SILVA BJ, DA SILVA RR, RODRIGUES AP, FARIAS LH, DO NASCIMENTO JL et al. Physalis angulata induces death of promastigotes and amastigotes of Leishmania (Leishmania) amazonensis via the generation of reactive oxygen species. Micron 2015; 82: 25-32. https://doi.org/10.1016/j. micron.2015.12.001

[61] KOZICS K, KLUSOVA V, SRANCIKOVA A, MUCAJI P, SLAMENOVA D et al. Effects of Salvia officinalis and Thymus vulgaris on oxidant-induced DNA damage and antioxidant status in HepG2 cells. Food Chem 2013; 141: 2198-2206. https://doi.org/10.1016/j.foodchem.2013.04.089

[62] HORVATHOVA E, KOZICS K, SRANCIKOVA A, HUNAKOVA L, GALOVA E et al. Borneol administration protects primary rat hepatocytes against exogenous oxidative DNA damage. Mutagenesis 2012; 27: 581-588. https://doi. org/10.1093/mutage/ges023

[63] HORVATHOVA E, SRANCIKOVA A, REGENDOVA-SEDLACKOVA E, MELUSOVA M, MELUS V et al. Enriching the drinking water of rats with extracts of Salvia officinalis and Thymus vulgaris increases their resistance to oxidative stress. Mutagenesis 2016; 31:51-59. https://doi.org/10.1093/mutage/ gev056

[64] VENUKUMAR MR, LATHA MS Antioxidant activity ofcurculigo orchioides in carbon tetrachloride-induced hepatopathy in rats. Indian J Clin Biochem 2002; 17: 80-87. https://doi. org/10.1007/BF02867976

[65] CADENAS E, DAVIES KJ Mitochondrial free radical generation, oxidative stress, and aging. Free Radic Biol Med 2000; 29: 222-230. https://doi.org/10.1007/BF02867976

[66] LINDEMAN JH, VAN ZOEREN-GROBBEN D, SCHRIJVER J, SPEEK AJ, POORTHUIS BJ et al. The total free radical trapping ability of cord blood plasma in preterm and term babies. Pediatr Res 1989; 26: 20-24. https://doi. org/10.1203/00006450-198907000-00008

[67] ARAGON G, YOUNOSSI ZM When and how to evaluate mildly elevated liver enzymes in apparently healthy patients. Cleve Clin J Med 2010; 77: 195-204. https://doi.org/10.3949/ ccjm.77a.09064

[68] Predes FS, Pinto Da Matta SL, Monteiro JC, De Oliveira TT Investigation of liver tissue and biochemical parameters of adult Wistar rats treated with Arcticum lappa. L Braz Arch Biol Technol 2009; 52: 335-340. https://doi.org/10.1590/ $\underline{\text { S1516-89132009000200010 }}$

[69] RAMAIAH SK A toxicologist guide to the diagnostic interpretation of hepatic biochemical parameters. Food Chem Toxicol 2007; 45: 1551-1557. https://doi.org/10.1016/j. fct.2007.06.007

[70] EL-NEKEETY A, MOHAMED SR, HATHOUT AS, HASSAN NS, ALY SE, ABDEL-WAHHAB MA Antioxidant properties of Thymus vulgaris oil against aflatoxin-induced oxidative stress in male rats. Toxicon 2011; 57: 984-991. https://doi. org/10.1016/j.toxicon.2011.03.021

[71] ABD EL KADER M, MOHAMED NZ Evaluation of protective and antioxidant activity of thyme (Thymus vulgaris) extract on paracetamol-induced toxicity in rats. Aust J Basic Appl Sci 2012; 6: 467-474. 